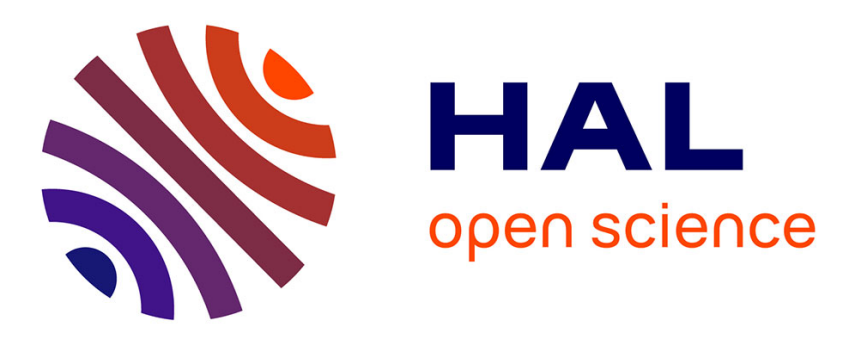

\title{
Effect of selective logging on stand structure and tree species diversity in a subtropical evergreen broad-leaved forest
}

Lichao Wu, Jie Liu, Atsushi Takashima, Keiichi Ishigaki, Shin Watanabe

\section{- To cite this version:}

Lichao Wu, Jie Liu, Atsushi Takashima, Keiichi Ishigaki, Shin Watanabe. Effect of selective logging on stand structure and tree species diversity in a subtropical evergreen broad-leaved forest. Annals of Forest Science, 2013, 70 (5), pp.535-543. 10.1007/s13595-013-0292-x . hal-01201498

\author{
HAL Id: hal-01201498 \\ https://hal.science/hal-01201498
}

Submitted on 17 Sep 2015

HAL is a multi-disciplinary open access archive for the deposit and dissemination of scientific research documents, whether they are published or not. The documents may come from teaching and research institutions in France or abroad, or from public or private research centers.
L'archive ouverte pluridisciplinaire HAL, est destinée au dépôt et à la diffusion de documents scientifiques de niveau recherche, publiés ou non, émanant des établissements d'enseignement et de recherche français ou étrangers, des laboratoires publics ou privés. 


\title{
Effect of selective logging on stand structure and tree species diversity in a subtropical evergreen broad-leaved forest
}

\author{
Lichao Wu • Jie Liu • Atsushi Takashima • \\ Keiichi Ishigaki $\cdot$ Shin Watanabe
}

Received: 4 December 2012 / Accepted: 22 April 2013 /Published online: 24 May 2013

(C) INRA and Springer-Verlag France 2013

\begin{abstract}
- Context Selective logging followed by natural regeneration is rarely employed for restocking subtropical evergreen broad-leaved forests in East Asia compared with the use of clear-cutting.

- Aims To clarify the succession of these forests, the effects of selective logging on stand structure, species diversity, and community similarity were studied in a mature and regenerating forest in Okinawa, Japan.

- Methods Four study plots were established, and trees $\geq 1.2 \mathrm{~m}$ height were identified by species name, tree height, and diameter at breast height.

- Results The results showed that the species composition of regenerating forest was similar to mature forest; however, the
\end{abstract}

Handling Editor: Douglass Jacobs

Contribution of co-authors Lichao Wu: Writing the paper, field work Jie Liu: Running the data analysis

Atsushi Takashima: Supervising the work

Keiichi Ishigaki: Field work

L. $\mathrm{Wu} \cdot \mathrm{J}$. Liu

Key Laboratory of Cultivation and Protection for Non-Wood Forest Trees of National Ministry of Education,

College of Forestry, Central South University of Forestry and Technology, Shaoshan South Road, No. 498,

Changsha 410004, China

L. Wu

e-mail: wulichao@sina.com

\section{A. Takashima}

Subtropical Field Science Center, Faculty of Agriculture,

University of the Ryukyus, 685 Yona,

Kunigami, Okinawa 905-1427, Japan

$\mathrm{K}$. Ishigaki $\cdot \mathrm{S}$. Watanabe $(\square)$

Iriomote Station, Tropical Biosphere Research Centre,

University of the Ryukyus,

Taketomo-Cho, Okinawa 907-1541, Japan

e-mail: iriomotejima@mac.com former had a greater species density and Shannon-Wiener index than the latter. Castanopsis sieboldii and Distylium racemosum, the predominant trees in the mature forest, continued to dominate the regenerating forest, with a broad layer distribution. High Sørensen and Jaccard community similarity indices for mature and regenerating forest indicated that the regeneration occurred in a progressive succession.

- Conclusion The similar species composition and stand structure for both mature and regenerating forest, and the higher species diversity for the latter, provided no evidence of forest degeneration and suggested that the regenerating forest may develop into a stand similar to preselective logging forest.

Keywords Selective logging $\cdot$ Natural regeneration $\cdot$ Stand structure $\cdot$ Species diversity $\cdot$ Evergreen broad-leaved forest

\section{Introduction}

The selective logging system is one of the most widely employed methods for commercial timber production in tropical forests, with clear-cutting more commonplace (Andrej et al. 2007; Bischoff et al. 2005; Castro-Luna et al. 2011). Selective logging can benefit conservation and sustainability of the forest resource as well as enhance environmental stability and quality, because trees can generate from not only the residual trees but also stump sprouts, new seedlings, and seedling banks (Okuda et al. 2003; Pakhriazad et al. 2004; Rodriguez-Calcerrada et al. 2011). However, in the subtropics, especially in East Asia, such as in China, Korea, and Japan, selective logging is not a popular practice for the regeneration of evergreen broad-leaved forest (EBLF), which is an important global vegetation formation that contributes to both the biodiversity and the sustainable development in subtropical regions (Wang et al. 2007; Wu et al. 2006). 
The primary reason for the unpopularity of selective logging of EBLF in these regions is its uncertainty of secondary succession, which may result in inappropriate forest structure, low volume production of target species because of low density, and poor distribution of the primary target trees, as well as significant invasion of tree species of low commercial value (Aramoto et al. 1977; Wang et al. 2007). Secondly, selective logging may not be suitable for large-scale operations because it is a labor-intensive and high-cost method compared with clear-cutting (Aramoto et al. 1977; Watanabe 2003). For these reasons, natural regeneration with selective logging has rarely been used for restocking of EBLFs in East Asia. As a consequence, the natural regeneration of EBLFs in subtropical regions has been a matter of concern for a long time (Aramoto et al. 1977), and following the rapid reduction in natural EBLFs in subtropical regions in recent decades, there have been increasing calls for the protection and restoration of these forests because of environmental and natural conservation benefits (Kira 1991). Although a number of studies on forest natural regeneration have been undertaken in subtropical regions, most of them have focused on deciduous or coniferous forests (Carlos et al. 1994; Vincent et al. 2000), not on EBLFs. There is a pressing need to elucidate the effects of selective logging on natural regeneration, stand structure, species diversity, and the abundance of plant species in EBLF, and to make the systems practical for local people from both ecological and silvicultural standpoints.

Okinawa, a unique subtropical county in Japan, consists of the southernmost islands of the country and is characterized by a subtropical maritime climate. In the northern part of Okinawa Island, well-developed subtropical EBLF dominated by Castanopsis sieboldii is widely distributed with other associated EBLF trees, such as Distylium racemosum, Schima wallichii ssp. liukiuensis, and Persea thunbergii (Miura and Yamamoto 2003; Xu et al. 2001). With the rapid development of tourism in Okinawa in recent decades, conservation of such unique forest resources in Japan has been emphasized and is now an urgent project aimed at protecting the EBLFs (Shinzato et al. 1995, 2000). To realize these objectives, and to establish working techniques of forest management, experimental studies on clear-cutting (Shinzato et al. 2000; Wu et al. 2008), strip clear-cutting (Wu et al. 2012), and selective logging (Shinzato et al. 1995; Wu et al. 2006) in EBLF followed by natural regeneration were carried out. Since the selective logging system is relatively new to the region, we do not know enough about the dynamics of these types of forests after selective logging.

This study was designed to examine the effects of selective logging on the stand structure, species diversity, and tree community similarity of subtropical EBLF. Taking previous studies into account, we hypothesized that (1) regenerating plots after selective logging would have higher tree species diversity than the pre-mature plots and (2) the community composition in regenerating plots would be similar to that in the pre-mature plots. In order to test these hypotheses, we focused on both commercial timber species and nontimber species for trees with a stem height $\geq 1.2 \mathrm{~m}$.

\section{Materials and methods}

\subsection{Study site}

The study was carried out at Yona Field, Subtropical Field Science Center, Faculty of Agriculture, University of the Ryukyus, located in the northern part of Okinawa Island, southern Japan $\left(26^{\circ} 45^{\prime} \mathrm{N}\right.$ and $\left.128^{\circ} 13^{\prime} \mathrm{E}\right)$. The region is characterized by a subtropical maritime climate with abundant rainfall throughout the year. Typhoons with strong winds and rain frequently strike the island from July to October. It never freezes in winter, and the temperature does not fall below $2.0^{\circ} \mathrm{C}$. The mean monthly maximum temperature and mean monthly minimum temperature are $32.1{ }^{\circ} \mathrm{C}$ (in August) and $10.8{ }^{\circ} \mathrm{C}$ (in February), respectively. The annual precipitation averages from 1,900 to $4,000 \mathrm{~mm}$ year $^{-1}$ (mean, $2,750 \mathrm{~mm}$ year $^{-1}$ ), with a mean annual temperature of $21.8^{\circ} \mathrm{C}$.

The topography of the area is hilly, with a gradient of $15^{\circ}$, and the altitude ranges from 320 to $350 \mathrm{~m}$ above sea level. The soil type of the study area is Xanthi-Udic Ferralosols, which derives mainly from shale and Tertiary sandstone. The study area before selective logging was a mature EBLF dominated by $C$. sieboldii, a long-lived climax species. The forest before the experiment had not received any management treatment such as logging or thinning since 1954. This type of forest has a relatively low canopy (usually less than $15 \mathrm{~m}$ tall) compared with other subtropical EBLF forests on mainland Japan (usually over $25 \mathrm{~m}$ tall). The mean basal area of the forests for trees with a diameter at breast height $(\mathrm{DBH}) \geq 3.0 \mathrm{~cm}$ was estimated to be $55 \mathrm{~m}^{2} \mathrm{ha}^{-1}$ (Xu et al. 2001), and the mean tree height was $8.5 \mathrm{~m}$ with a mean DBH of $10.5 \mathrm{~cm}$ for trees with a $\mathrm{DBH} \geq 4.0 \mathrm{~cm}$ (unpublished data). The present study site is located in a typical forest in the region, in which $C$. sieboldii shared $64.7 \%$ of the total stand volume with a mean basal area $61.7 \mathrm{~m}^{2} \mathrm{ha}^{-1}$ for all trees higher than $1.2 \mathrm{~m}$.

\subsection{Experimental design}

Four sample plots (each $20 \mathrm{~m} \times 10 \mathrm{~m}$ in size) were established as two adjacent parallel rows (two plots each) in the center of a 0.44-ha study area in the typical mature EBLF described above, in 1994. Each plot was divided into two $10 \mathrm{~m} \times 10 \mathrm{~m}$ subplots, with 25 cells $(2 \mathrm{~m} \times 2 \mathrm{~m})$ for ease of investigation. In the center of each subplot, a $1 \mathrm{~m} \times 1 \mathrm{~m}$ quadrat was set up for plant survey. Prior to the selective 
logging, trees $\geq 1.2 \mathrm{~m}$ in height were investigated cell by cell in the study plots, recording the species name, tree height, and DBH. Trees $<1.2 \mathrm{~m}$ in height and all plants present in each quadrat were also identified, including species name and height. In February 1994, all trees $(\mathrm{DBH} \geq 8.0 \mathrm{~cm}$ ) that may have commercial value were felled at their base, approximately $0.2 \mathrm{~m}$ above the soil surface, in the whole study area. The total harvest intensity in terms of stems was $7.1 \%$. The basal area of the study plots was reduced to $12.9 \mathrm{~m}^{2} \mathrm{ha}^{-1}$ for the residual unlogged trees ( $\geq 1.2 \mathrm{~m}$ in height) immediately after the selective logging in 1994. C. sieboldii, the primary target species, had the highest harvest intensity of $50.3 \%$. The forest was then left undisturbed by natural regeneration until the next tree survey, in December 2002.

Trees $\geq 1.2 \mathrm{~m}$ in height in the study plots were termed "overstory" species, while trees $<1.2 \mathrm{~m}$ in height and all plants in each quadrat were termed "understory." A plot before selective logging in the study area was termed a "mature" plot, while a plot in the secondary forest restocked by natural regeneration in 2002 was denoted a "regenerating" plot.

To forecast the dynamics of the forest layer structure, the woody plants (phanerophytes) enumerated in the survey were classified as megaphanerophytes (Mega; arbor), mesophanerophytes (Meso; mid-arbor), microphanerophytes (Micro; sub-arbor), and nanophanerophytes (Nano; shrub), according to Flora of the Ryukyus (Hatusima 1971). The nomenclature of species in this paper also follows Flora of the Ryukyus.

\subsection{Data analysis}

The species importance value (IV) was evaluated according to Basnet (1992) as follows:

$\mathrm{IV}=(\mathrm{RD}+\mathrm{RBA}) / 2$

where $\mathrm{RD}$ is the relative density, calculated as the number of stems of a given species in plots, divided by the total number of stems of all species within the same plots (in percent), and RBA is the relative basal area, calculated as for the RD, using the basal area instead of the number of stems (in percent). The dominant species were defined as those with IVs over 5.0.

The Shannon-Wiener index $\left(H^{\prime}\right)$ and the evenness index $(E)$ were estimated for species diversity as follows:

$H^{\prime}=-\sum_{i=1}^{s} p_{i} \log 2 p_{i}$

$E=H^{\prime} / \log _{2} S$

where $S$ is the total number of species encountered in a given plot and $p_{i}$ is the proportion of trees of the $i$ th species (Magurran 1988).
The degree of community similarity between the study plots was calculated using the Sørensen coefficient of community (Sørensen 1948) and the Jaccard similarity coefficient (Mueller and Ellenberg 1974):

$\mathrm{CC}=2 c /(a+b)$

$\mathrm{BC}=c /(a+b-c)$

where CC is the Sørensen coefficient of community, BC is the Jaccard coefficient, $a$ is the number of tree species in plot $\mathrm{A}, b$ is the number of tree species in plot $\mathrm{B}$, and $c$ is the number of species shared by both plots.

The statistical difference in the IV between mature and regenerating plots for each species was analyzed using oneway analysis of variance. The DBH, basal area, $S, H^{\prime}$, and $E$ for the mature and regenerating plots were analyzed using two-way analysis of variance, with one factor being forest type (mature or regenerating plot) and the other four phanerophyte types. The differences in tree size class distribution patterns for dominant species between the mature and the regenerating plots were examined by the Mann-Whitney $U$ test. Statistical analyses were completed with SPSS 15.0.

\section{Results}

\subsection{Species composition and species diversity}

A total of 27 families, 48 genera, and 65 overstory tree species were identified in the mature plots, while the corresponding values in the regenerating plots were 31,57 , and 82 , respectively. The number of species $(S)$ was significantly higher in the regenerating plots than in the mature plots (Fig. 1a; $F=25.74, p<0.001)$. Four dominant species, according to their IVs, were present in the mature plots (Table 1): $C$. sieboldii $(\mathrm{IV}=27.3)$, D. racemosum (15.3), Ardisia quinquegona (9.1), and Camellia japonica (5.7). C. sieboldii (IV=16.3), D. racemosum (12.1), and A. quinquegona (9.5) reappeared as dominant tree species in the regenerating plots. C. sieboldii exhibited significant decreases in the mean IV in the regenerating plots (range, 13.6-22.1) relative to mature plots (range, 22.1-31.3), although it ranked as the primary dominant species in both the mature and the regenerating plots $(F=15.82, p=0.007)$. For other dominant species, the IV values did not differ significantly between the mature and the regenerating plots $(p>0.05)$. However, $C$. japonica (5.7), one of the primary dominant Micro species, became nondominant (3.9) in the regenerating plots, although the difference was not significant between the mature and regenerating plots $(F=2.42, p=0.171)$.

Selective logging affected the relative abundance of plant life (Fig. 1a). Statistical analysis showed significant differences among phanerophyte types, of which Micro species 

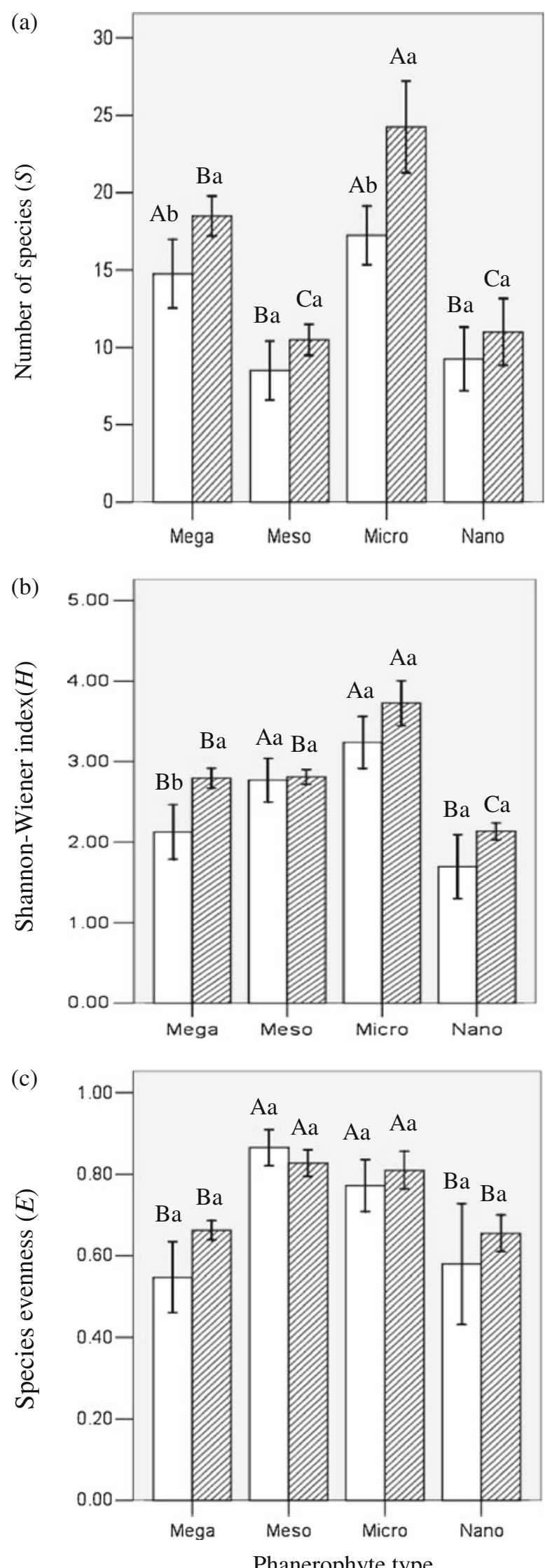

Mature

Phanerophyte type
4 Fig. 1 a Changes (mean $\pm \mathrm{SE}$ ) of the number of tree species, $\mathbf{b}$ the Shannon-Wiener index, and c species evenness for mature and regenerating plots following 8 years of selective logging in an EBLF in Okinawa. Significant differences are indicated by capital letters for the four phanerophyte types and by corresponding lowercase letters for mature and regenerating plots based on least significant difference (LSD) comparison $(p \leq 0.05)$

had the highest $S$ values, followed by Mega, Nano, and Meso $(F=57.12, p<0.001)$. Meso and Mega forms increased by one and two species, respectively, in the regenerating plots according to the investigation data, but Micro and Nano forms increased by six and eight species, respectively, indicating that the increase of $S$ in the regenerating plots was mainly from Micro and Nano phanerophyte types, rather than from Meso and Mega species. In addition, all the primary tree species occurred in the mature plots before selective logging reoccurred in the regenerating plots.

The mean $H^{\prime}$ value of overstory trees in the regenerating plots was significantly higher than that in the mature plots (Fig. 1b, $F=19.05, p<0.001$ ). The mean $E$ index, however, was not significantly different between mature and regenerating plots (Fig. 1c; $F=3.49, p=0.074$ ).

\subsection{Characteristics of stand structure}

The mean density of overstory trees in the regenerating plot (a total of 89,800 stems ha $^{-1}$ ) following 8 years of selective logging (Fig. 2a; $F=188.26, p<0.001$ ) was significantly higher than that in the mature plot (a total of 31,850 stems $\left.\mathrm{ha}^{-1}\right)$. Significant differences occurred for mean stem densities among the four phanerophytes $(F=33.27, p<0.01)$. The densities of Mega, Meso, Micro, and Nano species in the mature plots were $12,313,3,288,7,850$, and 8,400 stems $\mathrm{ha}^{-1}$, respectively, whereas the corresponding values in the regenerating plots were $31,088,11,363,20,275$, and 26,875 stems ha $^{-1}$, respectively.

The mean basal area in the regenerating plot (a total of $\left.33.4 \mathrm{~m}^{2} \mathrm{ha}^{-1}\right)$ was noticeably lower than that $\left(61.7 \mathrm{~m}^{2} \mathrm{ha}^{-1}\right)$ in the mature plot (Fig. 2b; $F=80.35, p<0.001$ ), while significant differences also occurred among the four phanerophytes $(F=337.45, p<0.001)$. The basal areas of Mega, Meso, Micro, and Nano species were 47.1, 5.3, 8.6, and $0.7 \mathrm{~m}^{2} \mathrm{ha}^{-1}$, respectively, in the mature plots, while the corresponding values were $19.5,4.6,7.3$, and $1.9 \mathrm{~m}^{2} \mathrm{ha}^{-1}$, respectively, in the regenerating plots. Thus, selective logging did not result in degeneration of Mega species since the mature Mega species mentioned above were still dominant in the regenerating plot, with abundant stems and basal area.

Two distribution patterns for the tree size class were found for the dominant species (Fig. 3). A reverse-J-type distribution was observed for A. quinquegona, C. japonica, and $D$. racemosum, which had similar distributions in both 
Table 1 Comparison of species IV for the main tree species in mature and regenerating plots followed by 8 years of selective logging in an EBLF in Okinawa

\begin{tabular}{|c|c|c|c|c|c|c|c|c|c|c|c|c|c|c|}
\hline \multirow[t]{2}{*}{ Species } & \multirow[t]{2}{*}{ Type } & \multicolumn{6}{|c|}{ Regenerating plot } & \multicolumn{6}{|c|}{ Mature plot } & \multirow[t]{2}{*}{$p$ value } \\
\hline & & I & II & III & IV & Mean & SE & I & II & III & IV & Mean & SE & \\
\hline Ardisia quinquegona & Nano & 10.3 & 9.6 & 9.0 & 8.9 & 9.5 & 0.32 & 12.3 & 9.6 & 6.7 & 7.9 & 9.1 & 1.21 & 0.805 \\
\hline Camellia japonica & Micro & 2.3 & 3.5 & 2.5 & 6.9 & 3.8 & 1.07 & 5.3 & 4.7 & 5.4 & 7.3 & 5.7 & 0.56 & 0.171 \\
\hline Castanopsis sieboldii & Mega & 22.1 & 15.6 & 13.6 & 14.0 & 16.3 & 1.97 & 31.3 & 22.1 & 27.4 & 28.2 & 27.3 & 1.91 & $0.007^{* *}$ \\
\hline $\begin{array}{l}\text { Daphniphyllum } \\
\text { glaucescens }\end{array}$ & Mega & 1.3 & 1.8 & 1.5 & 3.9 & 2.1 & 0.60 & 1.6 & 3.3 & 5.1 & 2.8 & 3.2 & 0.73 & 0.298 \\
\hline Distylium racemosum & Mega & 8.0 & 12.9 & 14.0 & 13.5 & 12.1 & 1.39 & 11.7 & 21.2 & 15.9 & 12.2 & 15.3 & 2.19 & 0.270 \\
\hline Schima wallichii & Mega & 2.7 & 6.3 & 5.4 & 1.0 & 3.9 & 1.22 & 2.5 & 1.7 & 2.0 & 0.5 & 1.7 & 0.43 & 0.380 \\
\hline
\end{tabular}

The dominant species in each plot with an importance value $\geq 5.0$ are highlighted in bold

${ }^{* *} p<0.01$ indicates the level of significance of the differences between mature tree species and regenerating tree species

the mature and the regenerating plots $(p>0.05)$. Castanopsis sieboldii, Daphniphyllum glaucescens, and $S$. wallichii, which have a broad height distribution, exhibited a unimodal pattern characterized by having the highest frequency in the intermediate size layers and lower frequencies to the smaller and larger layers. Of these species, the tree size distribution patterns differed significantly for both $\underline{C}$. sieboldii $(p=0.018)$ and $S$. wallichii $(p=0.018)$ between mature and regenerating plots, but this was not the case for D. glaucescens, which had no significant difference $(p=0.09)$.

\subsection{Community similarity}

The $\mathrm{CC}$ and $\mathrm{BC}$ values for overstory trees in the mature and regenerating plots showed similar trends, although the $\mathrm{CC}$ values were slightly higher than the $\mathrm{BC}$ values (Table 2). The $\mathrm{CC}$ and $\mathrm{BC}$ values within whole plots were 87.1 and 77.1 , respectively. More than $77 \%$ of the community similarity indices reflected the high general similarity between the mature and regenerating plots following 8 years of selective logging.

\subsection{Understory changes}

The number of individuals for all plants and understory trees decreased from 278 in the mature quadrats to 254 in the regenerating quadrats (Table 3 ). However, the understory species increased from 44 in the mature quadrats to 56 in the regenerating quadrats. The regenerating quadrats had slightly higher $H^{\prime}$ and $E$ values (5.0 and 0.86 , respectively) compared with those in the mature quadrats (4.6 and 0.84, respectively). Eleven dominant tree species occurred either in the mature or the regenerating quadrats. Of these, one dominant tree species, A. quinquegona, was present in the mature quadrats; however, in the regenerating quadrats, Glochidion acuminatum and Rapanea neriifolia were also present as dominant species in addition to A. quinquegona.
For plants, nine dominant species were present in either the mature or the regenerating quadrats. Alpinia intermedia, Microlepia marginata, Psychotria serpens, and Smilax bracteata were present as dominant plant species in the mature quadrats; however, in the regenerating quadrats, only two of the primary species, $A$. intermedia and $P$. serpens, reappeared as dominant herb species. M. marginata had disappeared and $S$. bracteata had become non-dominant in the regenerating quadrats.

\section{Discussion}

We found that the primary dominant Mega species continued to be the dominant species in the regenerating plots in the early stage, suggesting that they might continue to dominate in the secondary forest in the future. These species contributed to a majority of the total basal area, over 31,088 stems $\mathrm{ha}^{-1}$ in the regenerating plot (Fig. 2). The high stump sprouting ability, low mortality rate of the residual trees, and abundance of seedling-origin stems of the primary dominant species may be responsible for the dominance of Mega species in the regenerating forest. $C$. sieboldii, which can be considered a climax species in this investigation, continued to rank as the primary dominant species, with the highest IV (16.3) in the regenerating plot. Previous studies clarify why $C$. sieboldii eventually reached the canopy layer and dominated the regenerating forest: $\mathrm{Wu}$ and coworkers (Wu and Shinzato 2003; Wu et al. 2006) found that $C$. sieboldii had a low stump mortality rate $(6.8 \%)$ with abundant fast-growing sprouts $\left(3,363\right.$ stems $\left.^{-1}\right)$ and seedlingorigin stems $\left(5,358\right.$ stems $\left.\mathrm{ha}^{-1}\right)$, contributing to both the highest stem numbers and the highest basal areas in the regenerating forest after selective logging. D. racemosum, the second dominant Mega species (IV=15.3) in the mature plot, was still ranked as the second dominant species (IV= 12.1) in the regenerating plot. This observation suggests that 

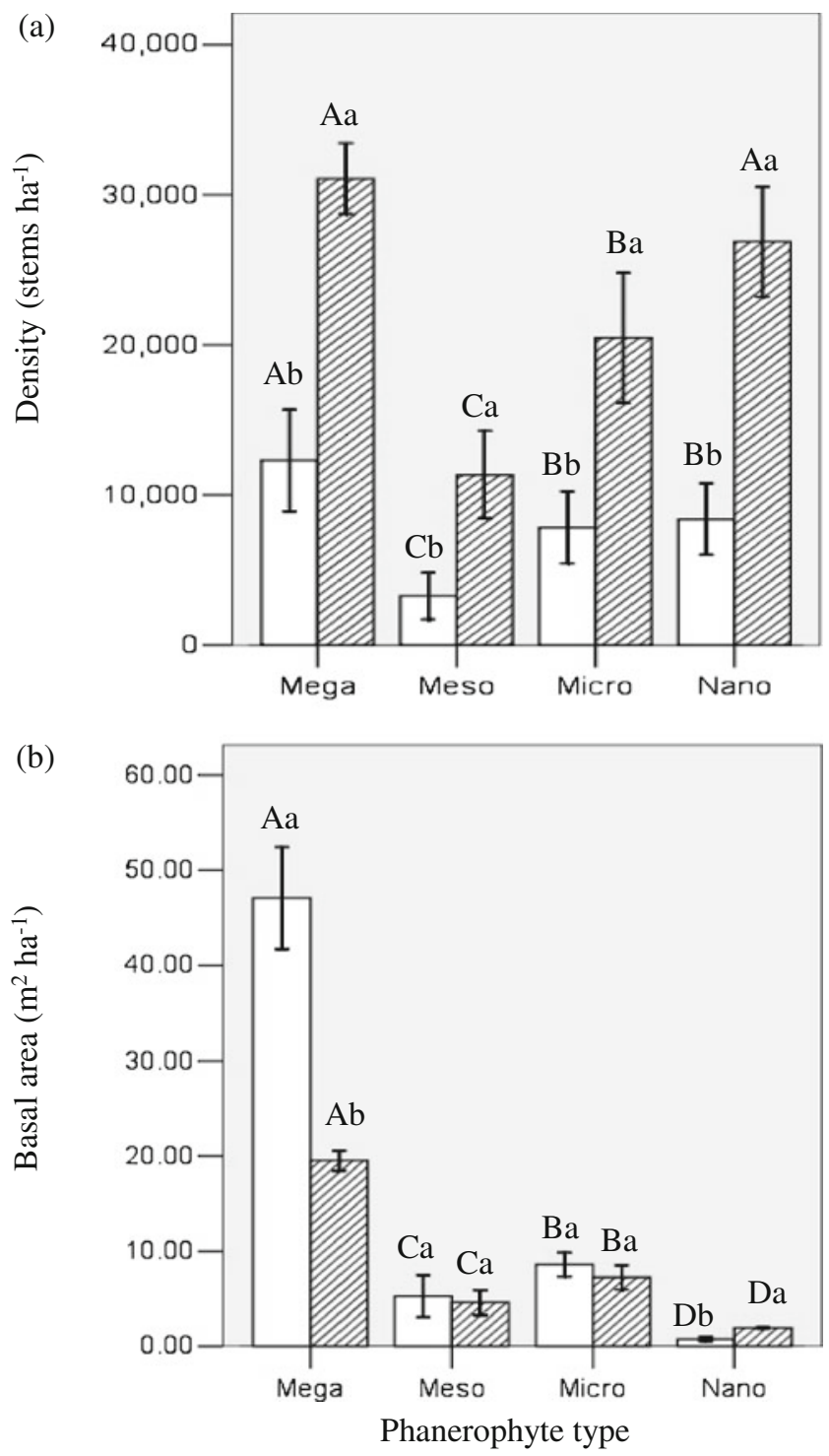

\section{$\square$ Mature $\quad \mathscr{W}$ Regenerating}

Fig. 2 Changes (mean \pm SE) in a stem density and $\mathbf{b}$ basal area between mature and regenerating plots following 8 years of selective logging in an EBLF in Okinawa. Significant differences are indicated by capital letters for the four phanerophyte types and by corresponding lowercase letters for mature and regenerating plots based on LSD comparison $(p \leq 0.05)$

Mega species might continue to dominate the plot in the future from a long-term perspective and that selective logging does not result in degeneration of Mega species.

While the above-mentioned Mega species reoccurred abundantly in the regenerating plots, a wide variety of Meso, Micro, and Nano species were also present in the regenerating plots (see Fig. 2), demonstrating that the forest structure was complex due to the efficacious development of multiple canopy layers. A. quinquegona, the primary dominant Nano species, is widely distributed in EBLF in East and Southeast Asia, and has a strong sprouting capacity after disturbance (Hatusima 1971; Shinzato et al. 2000). In the present study, it had a slightly higher IV (9.4) in the regenerating plots than that in the mature plots $(8.8)$ because of the abundance of residual stems $\left(4,250 \mathrm{stems} \mathrm{ha}^{-1}\right)$ and seedling-origin stems $\left(8,350 \mathrm{stems} \mathrm{ha}^{-1}\right)$ (Wu et al. 2006). However, C. japonica, the primary Micro species, was somewhat different from A. quinquegona: it had a low IV (3.9) and became a non-dominant species in the regenerating plots. The high stump mortality rate $(66.7 \%)$ and low sprouting ability of $C$. japonica after selective logging may be responsible for its non-dominance in the regenerating plots (Wu and Shinzato 2003).

We found that the regenerating plots after selective logging had greater $S$ and $H^{\prime}$ values (82 and 4.83, respectively) than those for the mature plots (65 and 4.35, respectively) for overstory trees, indicating that the selective logging did not result in a decrease in species diversity. The course of succession in Japanese subtropical forests seems to support the intermediate disturbance hypothesis (Aiba et al. 2001). The greater $S$ and $H^{\prime}$ values for regenerating forests may, however, occur simply because secondary forests contain both pioneer and climax tree species in the early regeneration stage (Aiba et al. 2001; Connell 1978). In the present study, not only all of the mature tree species but also 17 invading tree species (with Micro and Nano tree species especially abundant) were present in the regenerating plots. The presence of the mature tree species as well as the invasion of Micro and Nano tree species would appear to be responsible for the increase in the $S$ and $H^{\prime}$ values in the regenerating plots.

The high community similarity (77) between the abovementioned plots suggests that the selective logging followed by 8 years of natural regeneration did not result in a decrease in the community similarity indices. The $\mathrm{CC}$ value was calculated as 85.1 for mature forest and regenerating forest after 6 years of clear-cutting in a nearby EBLF study site, according to previous data (Shinzato et al. 2000). An 8-yearold strip-clear-cutting study has also shown a CC value of over 77 for primary and regenerating forests in another nearby EBLF study site (Wu et al. 2012). The CC values of over 77 in the present study suggest high community similarity between the mature and its regenerating plots (Bureau of Land Management 2001).

The vegetation census for both understory trees and plants conducted in the subplots revealed that the regenerating quadrats had higher $S, H^{\prime}$, and $E$ values than the mature quadrats. However, the number of individuals in the regenerating quadrats was considerably lower than that in the mature quadrats. Furthermore, we found that the decreased number of individuals was mainly from plant species, which showed a significant decrease, with 61 individuals in the regenerating quadrats, versus the 150 in the 

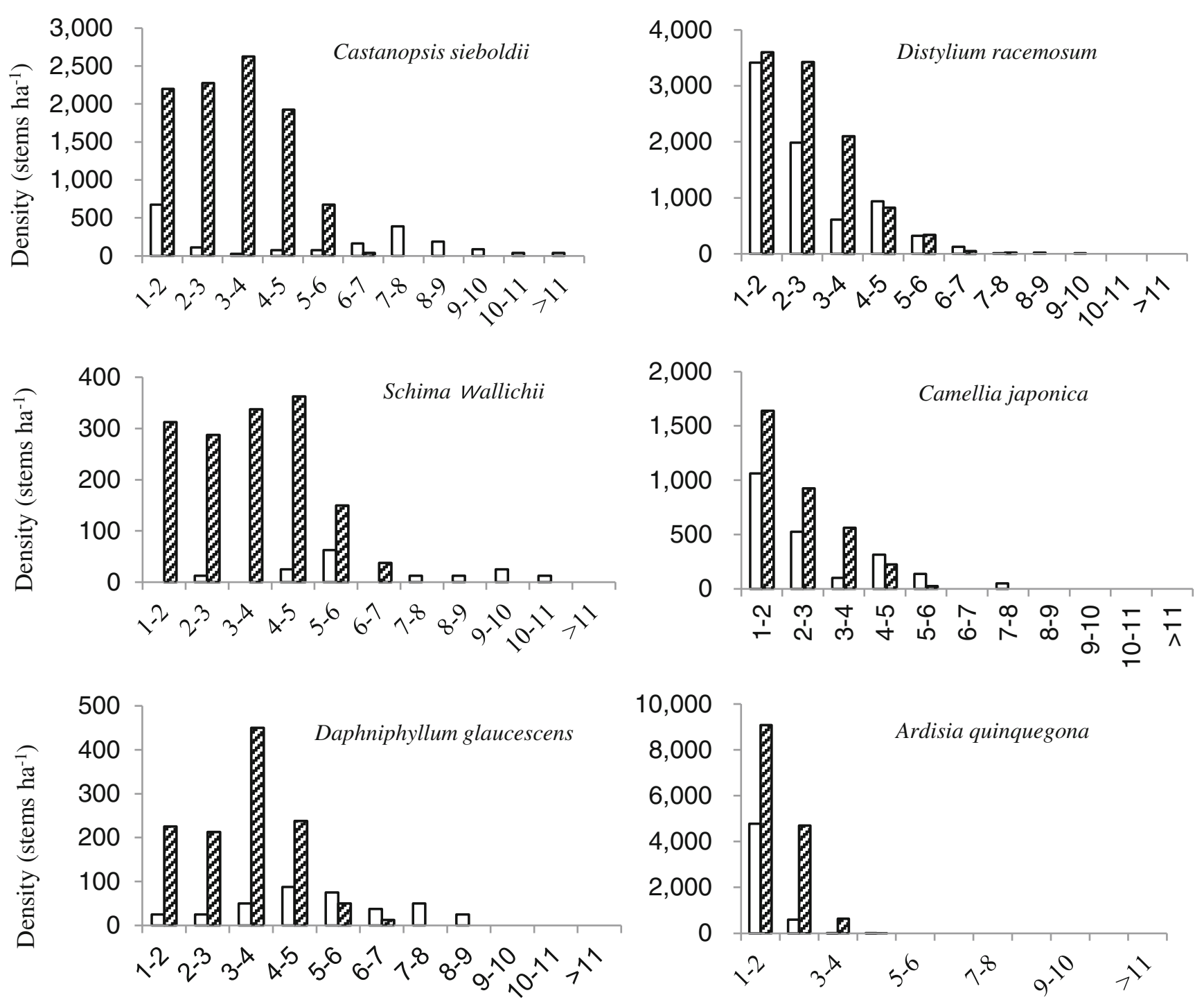

Tree height $(\mathrm{m})$

\section{Mature}

\section{$\mathscr{W}$ Regenerating}

Fig. 3 Tree size variations for the dominant species following 8 years of selective logging in an EBLF in Okinawa

mature quadrats (Table 3). The main reason for this difference may be the change in niche after selective logging, which resulted in the widespread death of the shade-tolerant species. For example, there were 31 individuals of the shade-tolerant plant $S$. bracteata in the mature quadrats; however, in the regenerating plots, there were only three individuals of the species, and it had disappeared from plots 1 and 2. M. marginata, another shade-tolerant species, was absent from the regenerating quadrats, whereas 24 individuals were present in the mature quadrats in the sampling subplots (Table 3 ). Similar results were also found in an EBLF restocked by natural regeneration after clear-cuttingburning on Iriomote Island, Okinawa, Japan. Wu et al. (2008) reported that $S$. bracteata was present in abundance in both clear-cutting-burning and clear-cutting-only plots (37 and 46 individuals, respectively) before treatment; however, it was absent after the two treatments followed by 20 years of natural regeneration. The more drastic the silvicultural treatments, the greater the decrease in shade-tolerant species. The above results from the plant census show that

Table 2 Community similarities for trees in mature and regenerating plots after 8 years of selective logging in an EBLF in Okinawa

\begin{tabular}{llllll}
\hline Plot & I & II & III & IV & Total \\
\hline Sørensen index (CC) & 82.5 & 81.0 & 89.4 & 93.2 & 87.1 \\
Jaccard index (BC) & 70.1 & 68.1 & 80.9 & 87.3 & 77.1 \\
\hline
\end{tabular}


Table 3 Number of individuals, species number $(S)$, Shannon-Wiener index $\left(H^{\prime}\right)$, and species evenness $(E)$ of dominant plant species (for both understory trees $<1.2 \mathrm{~m}$ height and all plants) and the number of stems/relative density (in percent) in the $1 \mathrm{~m} \times 1 \mathrm{~m}$ quadrats in an EBLF in Okinawa

\begin{tabular}{|c|c|c|c|c|c|c|c|c|c|c|}
\hline \multirow[t]{2}{*}{ Treatment } & \multicolumn{5}{|c|}{ Mature plot } & \multicolumn{5}{|c|}{ Regenerating plot } \\
\hline & I & II & III & IV & Total & I & II & III & IV & Total \\
\hline Number of individuals & 63 & 88 & 63 & 64 & 278 & 67 & 69 & 63 & 55 & 254 \\
\hline Species number $(S)$ & 20 & 30 & 21 & 15 & 44 & 29 & 24 & 34 & 25 & 56 \\
\hline Shannon-Wiener index $\left(H^{\prime}\right)$ & 4.04 & 4.30 & 4.00 & 3.10 & 4.60 & 4.40 & 3.90 & 4.70 & 4.10 & 5.00 \\
\hline Species evenness $(E)$ & 0.93 & 0.88 & 0.91 & 0.79 & 0.84 & 0.91 & 0.85 & 0.92 & 0.88 & 0.86 \\
\hline \multicolumn{11}{|l|}{ Dominant tree species } \\
\hline Adinandra ryukyuensis & & & & & & & & $5 / 7.9$ & & $5 / 2.0$ \\
\hline Ardisia quinquegona & $4 / 6.3$ & $8 / 9.1$ & $8 / \mathbf{1 2 . 7}$ & $4 / 6.3$ & $24 / 8.6$ & $8 / 11.9$ & $11 / \mathbf{1 5 . 9}$ & $9 / \mathbf{1 4 . 3}$ & $6 / 10.9$ & $34 / \mathbf{1 3 . 4}$ \\
\hline Camellia japonica & $5 / 7.9$ & & & & $5 / 1.8$ & $3 / 4.5$ & & $1 / 1.6$ & & $4 / 1.6$ \\
\hline $\begin{array}{l}\text { Cinnamomum } \\
\text { pseudo-pedunculatum }\end{array}$ & $1 / 1.1$ & $5 / 7.9$ & $2 / 3.1$ & $8 / 2.9$ & & & $1 / 1.6$ & & $1 / 0.4$ & \\
\hline Eurya japonica & & & & & & $3 / 4.5$ & $1 / 1.4$ & $4 / 6.3$ & & $8 / 3.1$ \\
\hline Glochidion acuminatum & & $2 / 2.3$ & & & $2 / 0.7$ & $6 / 9.0$ & $5 / 7.2$ & $2 / 3.2$ & $2 / 3.6$ & $15 / 5.9$ \\
\hline Neolitsea aciculata & & & & & & & $1 / 1.4$ & $2 / 3.2$ & $3 / 5.5$ & $6 / 2.4$ \\
\hline Persea thunbergii & & $4 / 4.5$ & & $2 / 3.1$ & $6 / 2.2$ & & $2 / 2.9$ & & $3 / 5.5$ & $5 / 2.0$ \\
\hline Rapanea neriifolia & $3 / 4.8$ & $2 / 2.3$ & $4 / 6.3$ & & $9 / 3.2$ & $7 / 10.4$ & $6 / 8.7$ & $2 / 3.2$ & $1 / 1.8$ & $16 / 6.3$ \\
\hline Schima wallichii & & & & & & $6 / 9.0$ & & $3 / 4.8$ & $1 / 1.8$ & $10 / 3.9$ \\
\hline Tarenna gracilipes & $5 / 7.9$ & $3 / 3.4$ & $1 / 1.6$ & & $9 / 3.2$ & & & & & \\
\hline \multicolumn{11}{|l|}{ Dominant plant species } \\
\hline Alpinia intermedia & $5 / 7.9$ & $9 / \mathbf{1 0 . 2}$ & $5 / 7.9$ & $8 / \mathbf{1 2 . 5}$ & $27 / 9.7$ & $4 / 6.0$ & $2 / 2.9$ & $1 / 1.9$ & $10 / \mathbf{1 8 . 2}$ & $17 / 6.7$ \\
\hline Diplazium donianum & $6 / 9.5$ & & & & $6 / 2.2$ & $1 / 1.5$ & & & & $1 / 0.4$ \\
\hline Dryopteris sordidipes & & & & & & & & & $8 / 14.5$ & $8 / 3.1$ \\
\hline Microlepia marginata & & & & $24 / 37.5$ & $24 / 8.6$ & & & & & \\
\hline Psychotria serpens & $7 / \mathbf{1 1 . 1}$ & $5 / 5.7$ & $9 / \mathbf{1 4 . 3}$ & $5 / 7.8$ & $26 / 9.4$ & $4 / 6.0$ & $15 / 21.7$ & $2 / 3.2$ & $2 / 3.6$ & $23 / 9.1$ \\
\hline Smilax bracteata & $6 / 9.5$ & 16/18.2 & $5 / 7.9$ & $4 / 6.3$ & 31/11.2 & & & $2 / 3.2$ & $1 / 1.8$ & $3 / 1.2$ \\
\hline Trachelospermum asiaticum & & $1 / 1.1$ & & $6 / 9.4$ & $7 / 2.5$ & $2 / 3.0$ & $5 / 7.2$ & $1 / 1.6$ & & $8 / 3.1$ \\
\hline Tylophora japonica & & $6 / 6.8$ & $6 / 9.5$ & & $12 / 4.3$ & & & $1 / 1.6$ & & $1 / 0.4$ \\
\hline Unknown species & $4 / 6.3$ & $7 / 8.0$ & $4 / 6.3$ & $2 / 3.1$ & $17 / 6.1$ & & & & & \\
\hline
\end{tabular}

Dominant species were designated as those with relative density $\geq 5.0$ in mature or regenerating forests in one plot. The dominant species are highlighted in bold

the selective logging resulted in a decrease in the number of individuals of plant species, followed by 8 years of natural regeneration. The decrease in the number of individual plants and the concomitant disappearance of shade-tolerant species demonstrates that understory plant restocking may be slower than tree regeneration after selective logging.

\section{Conclusions}

We close with three final points. First, a high stem density of mature dominant Mega species, such as $C$. sieboldii and $D$. racemosum, accompanied by a wide variety of other phanerophytes, indicates that the vertical structures of the forests were complex, with multiple canopy layers in the regenerating plot following 8 years of selective logging. Secondly, selective logging resulted in greater $\mathrm{S}$ and $H^{\prime}$ values and community similarity for woody species compared with the mature plots. The high diversity of tree species and the high community similarity demonstrate no evidence of degeneration in the regenerating plot, but rather a progressive succession, although selective logging did result in a decrease in plant species, according to the vegetation census. Thirdly, related to the above points, we can predict that the regeneration forest of subtropical EBLF after selective logging on Okinawa Island may gradually recover to a stand similar to the forest existing before selective logging. Since selective logging did not give evidence of forest degeneration from the present results, we consider that the selective logging system may be one of the best natural regeneration strategies to meet the dual objectives of timber production and environmental conservation. It should be pointed out, however, that since the investigation was on a small scale and in the early stage of forest 
regeneration, further study is needed with increased plot duplication to examine the effects of selective logging on the forest-regenerating dynamics of EBLF.

Acknowledgments We thank all the staff of Yona Field, Subtropical Field Science Center, Faculty of Agriculture, University of the Ryukyus, for assistance in the field census. We are indebted to Takakazu Shinzato, Emeritus Professor, University of the Ryukyus, for offering us the opportunity to conduct this study and invaluable advice and field support. We extend special thanks to Mr Masahiro Asato, a technical worker at the Subtropical Field Science Center, for his help with the field work.

Funding Financial support was partly provided by the National Department Public Benefit Research Foundation of State Forestry Administration of China (201104016) and a grant-in-aid for JSPS fellows in Japan.

\section{References}

Aiba S, Hill DA, Agetsuma N (2001) Comparison between old-growth stands and secondary stands regenerating after clear-felling in warm-temperate forests of Yakushima, southern Japan. For Ecol Manage 140:163-175

Andrej B, Ales K, Dusan R (2007) Effects of selective thinning on growth and development of beech (Fagus sylvatica L.) forest stands in south-eastern Slovenia. Ann For Sci 64:47-57. doi:10.1051/forest:2006087

Aramoto N, Tamaki K, Tsukayama K, Sunakawa S (1977) Studies on the working techniques of forest in the subtropics (III). On the stand composition in the experimental area by selection cutting system. Sci Bull Fac Agr Univ Ryukyus 24:771-781 (in Japanese with English abstract)

Basnet K (1992) Effect of topography on the pattern of trees in Tabonuco (Dacryodes excelsa) dominated rain forest of Puerto Rico. Biographica 24:31-42

Bischoff W, Newbery DM, Lingenfelder M, Schnaeckel R, Petol GH, Madani L, Ridsdale CE (2005) Secondary succession and dipterocarp recruitment in Bornean rain forest after logging. For Ecol Manage 218:174-192

Bureau of Land Management, Department of the Interior, U.S. (2001) Ecological site inventory. In Inventory and monitoring technical reference1734-7. Materials Distribution Services, Denver, Colorado, pp. 45

Carlos RS, Ikuo N, Kazuhiko O (1994) Age structural analysis of the natural regeneration process of a fir-hemlock secondary forest in southwest Japan. J Jpn For Soc 76:506-515

Castro-Luna AA, Castillo-Campos G, Sosa VJ (2011) Effects of selective logging and shifting cultivation on the structure and diversity of a tropical evergreen forest in south-eastern Mexico. J Trop For Sci $23: 17-34$

Connell JH (1978) Diversity in tropical rain forests and coral reefs. Science 199:1302-1310

Hatusima S (1971) Flora of the Ryukyus (including Amami Islands, Okinawa Islands, and Sakishima Archipelago). Soc Biol Edu Okinawa, Okinawa, pp 1-940 (in Japanese)

Kira T (1991) Forest ecosystem in East and Southeast Asia in globe perspective. Ecol Res 6:185-200
Magurran E (1988) Ecological diversity and its measurement. Croom Helm, London, p 179

Miura M, Yamamoto S (2003) Structure and dynamics of a Castanopsis cuspidata var. sieboldii population in an oldgrowth, evergreen, broad-leaved forest: the importance of sprout regeneration. Ecol Res 18:115-129

Mueller DD, Ellenberg H (1974) Aims and methods of vegetation ecology, 547th edn. Wiley Press, New York

Okuda T, Suzuki M, Adachi N, Quah ES, Hussein NA, Manokaran N (2003) Effect of selective logging on canopy and stand structure and tree species composition in a lowland dipterocarp forest in peninsular Malaysia. For Ecol Manage 175:297-320

Pakhriazad HZ, Shinohara T, Nakama Y, Yukutake K (2004) A selective management system(SMS): a case study in the implementation of SMS in managing the dipterocarp forests of Peninsular Malaysia. Kyushu J For Res 57:39-44

Rodriguez-Calcerrada J, Perez-Ramos IM, Ourcival JM, Limousin JM, Joffre R, Rambal S (2011) Is selective thinning an adequate practice for adapting Quercus ilex coppices to climate change? Ann For Sci 68:575-585. doi:10.1007/s13595-011-0050-x

Shinzato T, Taba K, Hirata E, Yamamori N, Aramoto M (1995) The secondary succession after a exploitation felling. (I) The damage of residual trees. Bull Kyushu For Soc 48:69-70

Shinzato T, Wu L, Nishihata O, Taba K, Enoki T, Hirata E (2000) Characteristics of natural sprout regeneration of evergreen broadleaved forest dominated by Castanopsis sieboldii in Okinawa: (I) studies on mortality and decay of stumps. Sci Bull Fac Agr Univ Ryukyus 47:145-157

Sørensen T (1948) A method of establishing groups of equal amplitude in plant sociology based on similarity in species content. Biol Skrl $\mathrm{K}$ danske Vidensk Selsk 5:1-38

Vincent R, Jean CR, André PP (2000) Establishment, growth and survival of natural regeneration after clearcutting and drainage on forested wetlands. For Ecol Manage 129:253-267

Wang X, Kent M, Fang XF (2007) Evergreen broad-leaved forest in Eastern China: its ecology and conservation and the importance of resprouting in forest restoration. For Ecol Manage 245:76-87

Watanabe S (2003) Evaluation and problems of natural forest management: technical issues occurring in Japan in which natural forest management failed to become established, resulting in forest degradation. J Jpn For Soc 85:273-281 (In Japanese)

Wu L, Shinzato T (2003) Decay of stumps and surviving state of residual trees 8 years post-selective logging in subtropical laurel forest in Okinawa, Japan. Sci Bull Fac Agr Univ Ryukyus 50:185-194

Wu L, Shinzato T, Aramoto M, Ishigaki C, Kuto T (2006) Contribution of regeneration sources in early succession stage of a subtropical evergreen broad-leaved forest after selective logging in Okinawa. Kyushu J For Res 59:75-81

Wu L, Shinzato T, Kudo T, Ishigaki C, Aramoto M (2008) Characteristics of a 20 -year-old evergreen broad-leaved forest restocked by natural regeneration after clearcut-burning. Ann For Sci 65:505

Wu L, Deng Y, Watanabe S, Shinzato T, Qin J, Zhong J, Zhang J (2012) Early response of stand structure and species diversity to strip-clearcut in a subtropical evergreen broad-leaved forest in Okinawa Island, Japan (online). New For. doi:10.1007/s11056012-9353-5

Xu X, Hirata E, Yoshihiro T, Takeo S (2001) Structure and species diversity of subtropical evergreen broad-leaved forest in northern Okinawa Island, Japan. J For Res 6:203-210 